African Crop Science Journal by African Crop Science Society is licensed under a Creative Commons Attribution 3.0 Uganda License. Based on a work at www.ajol.info/ and www.bioline.org.br/cs DOI: http://dx.doi.org/10.4314/acsj.v25i1.6S

\title{
RESILIENCE OF INNOVATION PLATFORMS WITHIN ARMED CONFLICTS: THE CASE OF INTEGRATED AGRICULTURAL RESEARCH FOR DEVELOPMENT FROM NORTH KIVU PROVINCE, DEMOCRATIC REPUBLIC OF CONGO
}

\author{
S. MAPATANO, S.O. NYAMWARO ${ }^{1}$, L. BAHIGA and A. MUKE ${ }^{2}$ \\ Diobass Platform in Kivu, P. O. Box 1914, Bukavu, Democratic Republic of Congo \\ ${ }^{1}$ CIAT Uganda, P. O. Box 6247, Kampala, Uganda \\ ${ }^{2}$ INERA-Mulungu, DS Bukavu, Democratic Republic of Congo \\ Corresponding author: mapatano_s@yahoo.fr, pdiobass@gmail.com
}

\begin{abstract}
The North Kivu Province in the eastern Democratic Republic of Congo has sporadically, and more recently, been disrupted by ethenic wars. These wars have caused displacement of people and destruction of economic resources in the Province. Many development initiatives have been arrested and others completely derailed. The SubSaharan Africa Challenge Program moved into the Province in 2008 and established four innovation platforms (IPs) under Integrated Agricultural Research for Development concepts, in Masisi and Rutshuru districts. The objective of this study was to identify mechanisms and strategies used by IPs to continue operating in amidst of wars and limited partner support. It is clear that the IAR4D concepts are functional even in times of conflicts, and without interventions of partners. The involvement of local authorities in the activities of IPs helped to preserve the property of the latter. The various mechanisms that were put in place to ensure continuity of IP activities included regular meetings at the antennae (sub-IP) levels, adoption of perennial crops to fight crop-raiding, moving seed stocks storage into more secure environments, solidarity among members of the IP and establishment of a communication system for securing people and property among others. It is observed that the IAR4D concept is a practical framework and a model for development of agricultural research for impact and provides a means of resilience that strengthens the cohesion of the population even in situations of conflicts.
\end{abstract}

Key Words: Sub-Saharan Africa Challenge Program

\section{RÉSUMÉ}

La province du Nord Kivu dans l'Est de République Démocratique du Congo, a sporadiquement, et plus récemment, été perturbée par des guerres d'ethnies. Ces guerres ont causé les déplacement des personnes et la destruction des ressources économiques dans la province. PLusieurs initiatives de développement ont été arrêtées et d'autres ont completement échoué. Le programme d'Enjeu de l'Afrique du Sub-Saharienne a été amené dans la province en 2008 et mise en place pour les plate-formes d'innovation sous les concepts de Recherches Agricoles Intégrées pour le Développement, dans les districts de Masisi et Rutshuru. L'objectf de cette étude était d'identifier les mécanismes et stratégies utilisés par les IPs pour continuer à opérer au beau milieu des guerres avec de supports limités des partenaires. C'est clair que les concepts de IAR4D sont fonctionnels même en période de conflits; et sans interventions des partenaires. Les implications des autorités locales dans les activités des IPs ont contribué à préserver les propriétés de ces dernières. Les divers mécanismes qui ont été mis en place pour assurer la continuité des activités de l'IP comprenaient des rencontres régulières aux niveaux des antennes (sub-IP), l'adoption des cultures pérennes pour lutter contre les ravages de cultures, les déplacements des stocks de semences des magasins vers des lieux mieux sécurisés, la solidarité entre les membres de l'IP et l'établissement d'un système de 
communication pour la sécurité des personnes et des biens entre autres. Il a été observé que le concept de IAR4D est un cadre pratique et un modèle d'impact pour la recherche agricole et de développement et fournit un moyen de résilience qui renforce la cohésion de la population même en situations de conflits.

Mots Clés: Africa Sub-Saharienne, Programme du défi

\section{INTRODUCTION}

According to the 2011 World Development report (World Bank, 2011), more than 1.5 billion people live in countries affected by violent conflicts. Between 2002 and 2011, the number of violent conflicts in Africa probably declined from 55 to about $24 \%$, respectively (Africa Progress Panel, 2011). But the democratic processes in many of the African countries are unfortunately accompanied by a number of conflicts, whose consequences on the prospects for human and economic development of the affected countries are devastating. By implication, few conflictaffected countries have achieved any meaningiful Millennium development (World Bank, 2011). Consequently, the conflictaffected African countries have experienced 'development in reverse' (Africa Progress Panel, 2011). On cursory observations, the populations of these countries are twice as vulnerable to malnutrition and their poverty rates are more than 20 points higher than those of other developing countries (Isumbisho and Sanginga, 2013).

The North Kivu Province is the epicenter of the wars in the Democratic Republic of Congo (DRC). It was in the North Kivu Province that a multitude of armed groups, more than two dozens, have been created over the past two decades. This is also the place where the warning signs and drums of Congo's wars have emerged through ethnic violence in 1993; and is still the same place today where there is great persistence forming the most formidable obstacles to stability.

This study attempts to understand, in the post-conflict context, what strategies have been put in place within the innovation platforms (IPs), to not only meet the current needs of the population, but also build dynamic mechanisms for agricultural and rural development that are capable of sustaining the affected populations to go beyond emergencies.

Contextual underpinnings of post-conflict events. The post-conflict context in North Kivu Province in DRC is very complex to define. While post-conflict refers to a conflict situation in which open warfare has come to an end, but remain open ended, where such situations remain tense for years or decades and can easily relapse back into large-scale violence (Junne and Verokren, 2005). In postconflict areas, there is a general absence of war, but not essentially real peace. Brahimi (2007) states that, 'the end of fighting does propose an opportunity to work towards lasting peace, but that requires the establishment of sustainable institutions capable of ensuring long-term security'. Prolonged conflict can lead to terrible resource losses (including human and physical devastation); it can also lead to breakdown of systems and institutions that enable a stable society work and these are the very systems that need to be revived (Brahimi, 2007). The term 'postconflict' does not signify the obliteration of the root causes of the outbreak of conflict in the first place. Nor does it imply complete cessation of hostilities that often recur even after the signing of peace agreements or the waging of elections. It frequently denotes merely an abatement of hostilities, or provides a 'window of opportunity' for peace in a conflict that can again escalate if mismanaged (Hamre and Sullivan, 2002; Fischer, 2004).

The experience of IPs developed by the Sub-Saharan Africa Challenge Programme (SSA CP) has shown their efficiency in a context where public institutions are still 
rebuilding. In the Lake Kivu Pilot Learning Site (LKPLS), IPs were formed around chosen agricultural value chains (including sorghum, potatoes, beans, bananas, and cassava among others) selected in participatory processes based on perceived importance by the stakeholders.

The formation and operationalisation of IPs in DRC as part of the LKPLS activities (Tenywa et al., 2011; Tenywa et al., 2013a; 2013b) were carried out through multi-phased participatory action learning approaches. This involved combination of iterative, participative, reflective and integrative desk modeling and field activities. IPs are composed of farmers and partners. Examples of selected partners and their roles in IP formation and functioning in LKPLS and DRC are well described in Tenywa et al. (2011, 2013a, 2013b). The objective of this study was to identify mechanisms and strategies used by IPs to continue operating in amidst of wars and limited partner support.

\section{METHODOLOGY}

This study was conducted in the four IPs, namely, Buuma, Musanganya, Muungano, and Maendeleo, all in the Nord-Kivu region, which is a province located at the eastern Democratic Republic of Congo. The Province borders Lake Kivu, Rwanda and Uganda in the east; and Orientale, Maniema and South Kivu provinces in the north and northwest, southwest, and southern respectively. Since 1998, North Kivu region has been politically unstable and one of the flashpoints in military conflicts in DRC (Wikipedia CIA, 2014).

Innovation platforms are approaches that were developed by the SSA CP to actualise the IAR4D concept. The IPs bring together different stakeholders, to identify solutions to common problems and to achieve common goals. In IPs, it is ensured that different interests are taken into account, and various group members contribute to finding solutions. Used by the private sector to gather information and improve networking among key stakeholders in a particular economic sector, IPs are now recognised by many development agencies as providing spaces for learning and change where groups or individuals with different backgrounds and interests - farmers, traders, food processors, researchers, government officials and others meet and interact (FARA, 2007; Birachi et al., 2013; Tukahirwa et al., 2013; Swaans et al., 2013; Adekunle et al., 2014; Schut et al., 2015).

Using the IP approaches, this study focused on the period between April 2012 and December 2013, which was the period of intense disorder caused by fighting between various armed groups. It was during this period that perhaps civil war climaxed in the North Kivu Province.

Guided by a developed structured questionnaire, eight focus group discussions (FGDs) and four key informant interviews (KIIs) were held with both the leaders and members of the four DRC IPs to solicit information on how IPs remained resilient in the midst of armed conflicts.

For purposes of this study, FGDs and KIIs were regarded as forms of group interviews that capitalised on communication between researchers and interviewed participants in order to generate data and information. Although the group interviews were used as quick and convenient ways to collect data and information from the IP members, simultaneously, the groups were explicitly used for group interactions as part of participatory methods to triangulate the collected data bases and information. Participants were encouraged to talk to one another; asking questions, exchanging anecdotes and commenting on each other's experiences and points of view. This method enabled us to get some success stories from participants, described in relation with their activities as IP members. Five key aspects were discussed and analysed, namely, membership, communication, status of technologies developed, access to market, and relation with local authorities. 


\section{RESULTS AND DISCUSSION}

Membership. Under normal circumstances, it would be expected that due to the disorders caused by the conflicts, the number of IP members should have automatically dwindled. On the contrary, this was not always the case in the North Kivu province (Fig. 1). In the Maendeleo and Buuma IPs, for example, the number of members increased even as the numbers decreased in the other two IPs (Muungano and Musanganya).

As will be noted in subsequent discussions, some of these differences are partly be explained by several factors including, the motivation of the leaders in IPs who encouraged and gave hope to membership cohesion and resilience. These leaders brought members together and encouraged them to help each other, particularly during the time of scarcity resulting from the conflicts. The types of activities carried out during the crises, included staying together in groups and organising men to be watching out for eruptions of troubles and warn members to be alert and hide or escape.

In contrast, the Muungano and Musanganya IPs were in difficult positions, given that they were located in heavily affected areas. IP Muungano was located where the rebels had set up their headquarters; while the Musanganya IP was actually the headquarters of the armed forces (FARDC) of the Democratic Republic of Congo.

It is important to note that in IPs where leadership was wanting, the number of members actually decreased (Fig. 1); while the opposite was observed where leaders of the IPs demonstrated championship and inspired the membership (Fig. 1). Despite irregular visits of facilitators during these troubled times, some IP members remained very active and actually attracted new membership. In fact, in such hardships it came together in solidarity to try to address multiple problems such as hunger, poverty, poor sanitation; and looked up for support for various victims in order to reduce their vulnerabilities. The

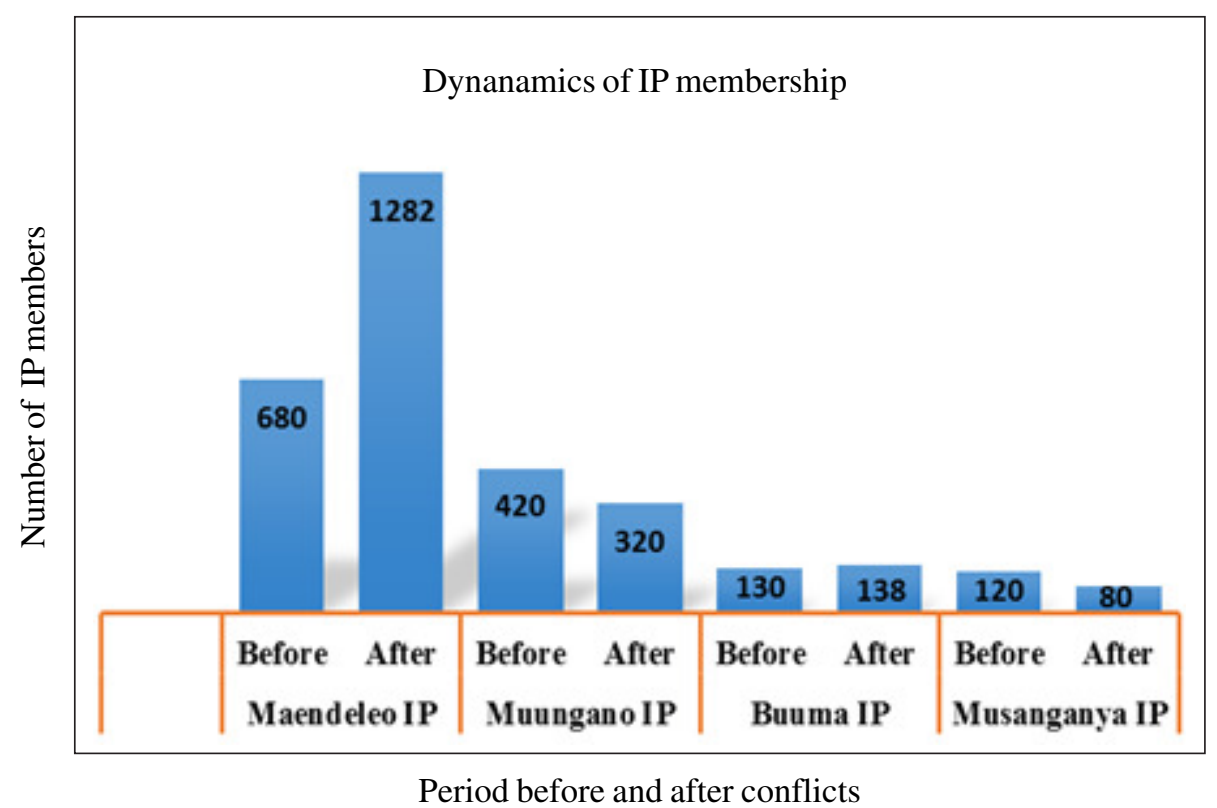

Figure 1. IP membership before and after the conflict period in the North Kivu province, eastern Democratic Republic of Congo. 
membership often tried to avoid marginalisation of members and became an expression of solidarity between individuals. More broadly, the fact of being members of the IPs, discussing problems together and realising the sharing of problems with other members, allowed members to create and even strengthen a sense of belonging to a group, and build or strengthen a collective identity.

To circumvent current difficulties and safeguard livelihoods, the good leadership IPs set up various strategies (Table 1), which were used to enhance communication and awareness of members for understanding, encouragement, and strengthening for them to cope with the situation. Special leadership committees formed visited members in their homes to discuss issues that emerged as a result of conflicts and, thus this expanded beyond initial IP objectives.

Also, the establishment and implementation of community activities was considered as an important and vital strategy to fight demotivation of members. The organisation and holding of regular meetings, and the introduction of livestock farming were some of the strategies used by the IP Buuma to retain its members and attract new ones. Beyond the features and interests defined at the outset, more holistic vision and integration of the realities of the time allowed the groups to live together; and welcome and accommodate new members.

Communication and IP operations. The various IP leaders were faced with different challenges (Table 2) to keep in touch with their members and other project partners. The greatest difficulty was lack of mobile air-time credit to interact with the antennas (sub-IPs) and members. It is also of interest to note that the government had blocked access to the telephone network to certain occupied areas. Further, it was difficult to get in touch with members because of the occupation of certain IP areas by the rebels and the occurrence of sporadic fighting from time to time.

To circumvent some of these communication difficulties, the IPs implemented some strategies (Table 3) to communicate with their members, namely: sending paper invitations (for all IPs), reading the releases in the churches, information sent directly to members at their homes. Sending phone short messages was selected by two IPs (Buuma and Muungano) to stay in touch with their members. Since the Maendeleo IP was used as an interception of rebel communications by the government intelligence services, the IP opted for a communication system of word of mouth to

TABLE 1. Strategies used to cope with and mitigate against difficulties encountered by IP membership during the conflict periods in Kivu Province, eastern Democratic Republic of Congo

\begin{tabular}{|c|c|c|c|c|c|}
\hline \multirow[t]{2}{*}{ Strategies } & \multicolumn{4}{|c|}{ IPs } & \multirow{2}{*}{$\begin{array}{l}\text { IPs using } \\
\text { strategy }\end{array}$} \\
\hline & Maendeleo & Muungano & Buuma & Musanganya & \\
\hline Sensitisation & 1 & 1 & 1 & 1 & 4 \\
\hline Community activities & 0 & 1 & 1 & 0 & 2 \\
\hline Door to door visits & 1 & 0 & 0 & 1 & 2 \\
\hline Introduction of livestock activities & 0 & 0 & 1 & 0 & 1 \\
\hline Organisation of regular meetings & 0 & 0 & 1 & 0 & 1 \\
\hline Exchange visits & 1 & 0 & 0 & 0 & 1 \\
\hline Total number of strategies used & 3 & 2 & 4 & 2 & 11 \\
\hline
\end{tabular}




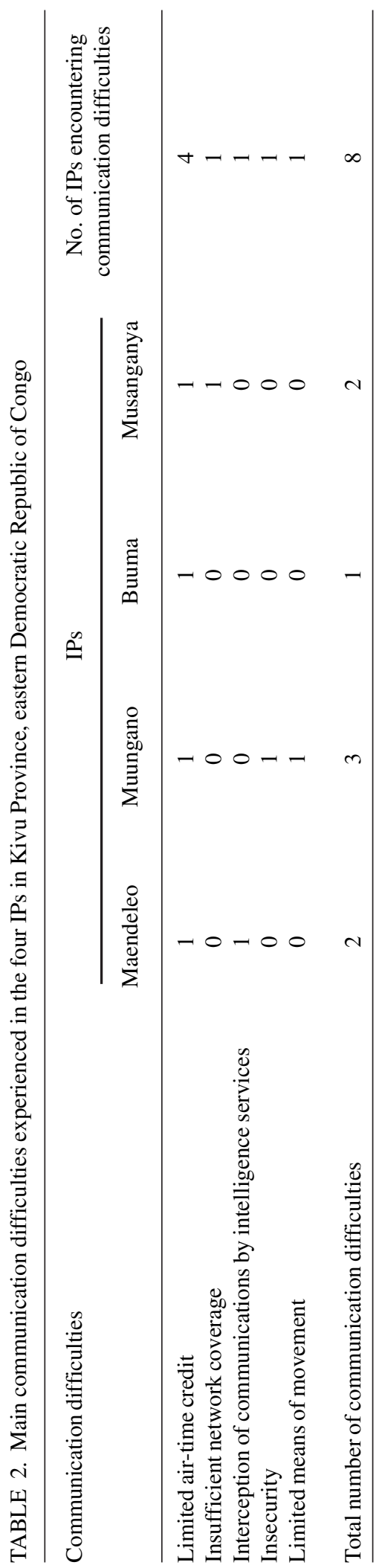

S. MAPATANO $e t$ al.

get in touch with its members (the members transmitted information between themselves).

Challenges of keeping in touch among IP members. Another problem that was experienced was the difficulty to stay in touch between and among IP members themselves. For instance, the fear of the armed forces occupier who made some of the IPs their operational headquarters was the main difficulty that prevented members from keeping in touch. In such areas, people were afraid of talking to each other for fear of being reported to the rebel authorities and get reprimanded, and perhaps killed. Insecurity also prevented members from visiting and staying in contact. Due to the presence of the government soldiers in the IP Musanganya, for instance, there was general lack of trust among members due to the IP leadership conflicts that caused some distrust to those who supported any leader. This also, resulted in lack of motivation on the part of members who did not support any of the parties in conflict.

Table 4 shows the different challenges faced by members of IPs to stay in contact between and amongst themselves. Different strategies were developed to overcome some of the difficulties of keeping in touch. However, these strategies were specific to each IP, which developed its own strategy to enhance communication between members to keep in touch (Table 5).

Difficulties encountered in monitoring IP activities. During the crises, IPs encountered various difficulties (Table 6) of which the most important included limited transport means to reach the antennas (sub-IPs); and insecurity on the roads leading to the various sites where the antennas were located. These difficulties hindered the running of the monitoring activities to the IP and antennae sites.

All the IPs had innovated similar strategies such as decentralisation of monitoring to circumvent the difficulties intracking the monitoring of activities. Although there were 
TABLE 3. Strategies implemented to overcome communication problems between the IPs and their members in Kivu Province, eastern Democratic Republic of Congo

\begin{tabular}{lccccc}
\hline Communication strategies & \multicolumn{3}{c}{ IPs } & \multirow{2}{*}{$\begin{array}{c}\text { Total number of } \\
\text { IPs using strategy }\end{array}$} \\
\cline { 2 - 5 } & Maendeleo & Muungano & Buuma & Musanganya & \\
\hline Invitations & 1 & 1 & 1 & 1 & 4 \\
Releases in churches & 1 & 1 & 0 & 1 & 3 \\
Door to door & 1 & 1 & 0 & 1 & 3 \\
Short message system & 0 & 1 & 1 & 0 & 1 \\
Word of mouth information & 1 & 0 & 0 & 0 & 13 \\
Total number of strategies & 4 & 4 & 2 & 3 & \\
\hline
\end{tabular}

TABLE 4. Key challenges faced by members in keeping in touch among themselves in the four IPs in Kivu Province, eastern Democratic Republic of Congo

\begin{tabular}{lccccc}
\hline Key challenges & \multicolumn{2}{c}{ IPs } & & $\begin{array}{c}\text { Total number } \\
\text { of IPs that } \\
\text { experienced } \\
\text { challenges }\end{array}$ \\
\cline { 2 - 5 } & Maendeleo & Muungano & Buuma & Musanganya & \\
Fear & 1 & 1 & 0 & 1 & 3 \\
Insecurity & 1 & 1 & 0 & 0 & 2 \\
Lack of communication & 1 & 0 & 1 & 0 & 2 \\
Lack of trust among members & 0 & 0 & 0 & 1 & 1 \\
Lack of motivation & 0 & 0 & 0 & 1 & 1 \\
Total number of challenges experienced & 3 & 2 & 1 & 3 & 9 \\
\hline
\end{tabular}

TABLE 5. Implementation strategies to circumvent the difficulties of communication among members to keep base in the four IPs in Kivu Province, eastern Democratic Republic of Congo

\begin{tabular}{|c|c|c|c|c|c|}
\hline \multirow[t]{2}{*}{ Implementation strategies } & \multicolumn{4}{|c|}{ IPs } & \multirow{2}{*}{$\begin{array}{l}\text { Total number } \\
\text { of IPs } \\
\text { practising } \\
\text { strategy }\end{array}$} \\
\hline & Maendeleo & Muungano & Buuma & Musanganya & \\
\hline $\begin{array}{l}\text { Creation of a system of savings and loan } \\
\text { for solidarity }\end{array}$ & 1 & 0 & 0 & 0 & 1 \\
\hline Awareness & 0 & 0 & 0 & 1 & 1 \\
\hline $\begin{array}{l}\text { Visits between members of the same } \\
\text { village }\end{array}$ & 1 & 0 & 0 & 0 & 1 \\
\hline Exchange visits & 0 & 0 & 1 & 0 & 1 \\
\hline Comforting visits & 0 & 1 & 0 & 0 & 1 \\
\hline Total number of strategies practised & 2 & 1 & 1 & 1 & 5 \\
\hline
\end{tabular}


also minor strategies such as relocation of community fields and rental of motorcycles used for monitoring, the overall IP management opted for decentralisation of monitoring of activities at each antenna and each village (Table 7). The activities were decided and implemented at each antenna, and then the reports were sent to the IP.

Market access. In addition to loss of life, armed conflicts caused great socio-economic losses, including losses of local resources within the local economies (Njingulula et al., 2014). As further noted from observations of Njingulula et al. (2014), the economies got weakened with the most vulnerable and affected groups increasingly getting dependent on humanitarian aid. The movement of goods was curtailed, not only because of the destroyed and dilapidated communications infrastructure, but also because of the deterioration of the networks and unpredictable dynamics of supply chains. The purchasing power of the local population fell very low because of the loss and narrow bases of the income sources.

Under such conditions, most local markets were disrupted and in fact destroyed for many months, their operational capacity and efficiency got very limited. However, certain other markets continued to operate at a relatively high level.

In addition to other difficulties (Table 8), the main difficulty regarding access to markets during the periods of crises was price fixing by the buyer because the markets were not crowded. The buyers who could reach these markets were few and ended up fixing the buying prices. This led to sharp depreciation

TABLE 6. Difficulties in monitoring of IP activities in Kivu Province, eastern Democratic Republic of Congo

\begin{tabular}{|c|c|c|c|c|c|}
\hline \multirow[t]{2}{*}{ Difficulties experienced } & \multicolumn{4}{|c|}{ IPs } & \multirow{2}{*}{$\begin{array}{l}\text { Total number } \\
\text { of IPs } \\
\text { experiencing } \\
\text { difficulties }\end{array}$} \\
\hline & Maendeleo & Muungano & Buuma & Musanganya & \\
\hline Lack of a transport & 1 & 1 & 1 & 1 & 4 \\
\hline Insecurity & 1 & 1 & 0 & 1 & 3 \\
\hline $\begin{array}{l}\text { Problems communicating with other } \\
\text { members }\end{array}$ & 0 & 1 & 0 & 0 & 1 \\
\hline Total number of difficulties experienced & 2 & 3 & 1 & 2 & 8 \\
\hline
\end{tabular}

TABLE 7. Strategies put in place to overcome the difficulties in the monitoring of IP activities in Kivu Province, eastern Democratic Republic of Congo

\begin{tabular}{|c|c|c|c|c|c|}
\hline \multirow[t]{2}{*}{ Monitoring strategies } & \multicolumn{4}{|c|}{ IPs } & \multirow{2}{*}{$\begin{array}{l}\text { Total number } \\
\text { of IPs } \\
\text { practising the } \\
\text { strategies }\end{array}$} \\
\hline & Maendeleo & Muungano & Buuma & Musanganya & \\
\hline $\begin{array}{l}\text { Decentralisation of monitoring to the } \\
\text { antennas }\end{array}$ & 1 & 1 & 1 & 1 & 4 \\
\hline Relocation of community fields & 0 & 1 & 0 & 0 & 1 \\
\hline Rental of motorcycles & 0 & 0 & 1 & 0 & 1 \\
\hline Total number of strategies practised & 1 & 2 & 2 & 1 & 6 \\
\hline
\end{tabular}


of the products, resulting in imperfect market situations prevailing. This is because the markets were controlled by rebel forces; hence very few buyers dared to participate in these markets. Produce en-route to markets suffered police road blocks and harassment, and imposed taxes that were levied arbitrarily and randomly. The IP Muungano encountered the most difficulties because of its position as the rebel headquarters.

Several strategies (Table 9) were developed by the IPs to circumvent the market access difficulties. The most important of these strategies were bartering (exchange of certain properties), selling directly in the field at harvesting and selling among IP members themselves. For IPs that were the occupied headquarters of either the rebel forces or the regular government troops during the crisis periods, the best strategy for circumventing difficulties in market access was the selling directly in the field during harvesting. This prevented thefts and various hassles along the way to markets or bulking stores. The sale of products between members and bartering were implemented in areas where insecurity was greatest and where market access was highly difficult. For the IP Buuma, which was not

TABLE 8. Key challenges encountered in market access in Kivu Province, eastern Democratic Republic of Congo

\begin{tabular}{lccccc}
\hline Key market access challenges & \multicolumn{2}{c}{ IPs } & $\begin{array}{c}\text { Total number } \\
\text { of IPs } \\
\text { experiencing } \\
\text { the challenges }\end{array}$ \\
\cline { 2 - 5 } & Maendeleo & Muungano & Buuma & Musanganya & M \\
Prices setting by the buyers & 1 & 0 & 1 & 1 & 3 \\
Police harassment & 1 & 1 & 0 & 0 & 2 \\
High taxes & 1 & 1 & 0 & 0 & 2 \\
Stealing & 0 & 1 & 0 & 1 & 1 \\
Markets controlled by the rebels & 0 & 1 & 0 & 0 & 1 \\
Limited agricultural feeder roads & 0 & 0 & 0 & 1 & 1 \\
Low product quality in the markets & 0 & 0 & 1 & 0 & 1 \\
Looting & 0 & 1 & 0 & 0 & 13 \\
Total number of challenges encountered & 3 & 5 & 2 & 3 & \\
\hline
\end{tabular}

TABLE 9. Strategies implemented to improve market access in the four IPs in Kivu Province, eastern Democratic Republic of Congo

\begin{tabular}{lccccc}
\hline Strategies of improving market access & \multicolumn{3}{c}{ IPs } & & $\begin{array}{l}\text { Total number } \\
\text { of IPs } \\
\text { practising } \\
\text { the strategies }\end{array}$ \\
\cline { 2 - 6 } & Maendeleo & Muungano & Buuma & Musanganya & \\
\hline Bartering & 1 & 0 & 0 & 1 & 2 \\
Sales at field level & 1 & 1 & 0 & 1 & 3 \\
Sales amongst members & 1 & 0 & 0 & 1 & 2 \\
Processing of cassava into white flour & 0 & 0 & 1 & 0 & 1 \\
Use of standard measuring units (Kg) & 0 & 0 & 1 & 0 & 1 \\
Staggered sales & 0 & 1 & 0 & 0 & 1 \\
Total number of strategies implemented & 3 & 2 & 2 & 3 & 10 \\
\hline
\end{tabular}


greatly affected by the conflict crisis, its major problem was more on improving the quality of its products to improve competitiveness, and using standard units of measurement to maximise its opportunities of improving profitability of the products.

Crop management challenges. Like market access, crop management was faced with many challenges; among the most important ones being crop theft and looting by the armed forces occupying these environments. However, as reported by the IPs, the crops suffered additional constraints as described in Table 10 .
Different strategies (Table 11) were employed to cope with the crop management difficulties across the affected IPs. Generally, the main solutions to ensure good crop management included guarding and staggering the crop sales. Here staggering crop sales implies harvesting and transporting only the quantities that will be sold and the rest remains in the field until another time harvesting will be required. To further protect crops, members of Rutshuru IPs (Muungano and Maendeleo) opted for the creation of false walls in their homes to hide harvests.

TABLE 10. Difficulties affecting crop management in the four IPs in Kivu Province, eastern Democratic Republic of Congo

\begin{tabular}{|c|c|c|c|c|c|}
\hline \multirow[t]{2}{*}{ Difficulties of crop management } & \multicolumn{4}{|c|}{ IPs } & \multirow{2}{*}{$\begin{array}{l}\text { Total number } \\
\text { of IPs } \\
\text { experiencing } \\
\text { the difficulties }\end{array}$} \\
\hline & Maendeleo & Muungano & Buuma & Musanganya & \\
\hline Theft & 1 & 1 & 1 & 1 & 4 \\
\hline $\begin{array}{l}\text { Pests and diseases - Banana bacterial } \\
\text { wilt (BXW) }\end{array}$ & 0 & 0 & 0 & 1 & 1 \\
\hline Poor storage infrastructure & 0 & 0 & 1 & 0 & 1 \\
\hline Post-harvest losses - pillage & 1 & 1 & 0 & 0 & 2 \\
\hline Post-harvest losses - rotting & 0 & 0 & 0 & 1 & 1 \\
\hline Unfavourable weather conditions & 1 & 0 & 0 & 0 & 1 \\
\hline Total number of difficulties & 3 & 2 & 2 & 3 & 10 \\
\hline
\end{tabular}

TABLE 11. Strategies used for circumventing crop management difficulties in the four IPs in Kivu Province, eastern Democratic Republic of Congo

\begin{tabular}{|c|c|c|c|c|c|}
\hline \multirow[t]{2}{*}{ Circumventing strategies } & \multicolumn{4}{|c|}{ IPs } & \multirow{2}{*}{$\begin{array}{l}\text { Total number } \\
\text { of IPs } \\
\text { using the } \\
\text { strategies }\end{array}$} \\
\hline & Iaendeleo & Muungano & Buuma & Musanganya & \\
\hline Guarding & 1 & 1 & 1 & 1 & 4 \\
\hline Staggered sales & 1 & 1 & 1 & 1 & 4 \\
\hline Direct sales after harvest & 0 & 1 & 1 & 1 & 3 \\
\hline Creating false walls in houses to hide harvests & 1 & 1 & 0 & 0 & 2 \\
\hline Total number of strategies & 3 & 4 & 3 & 3 & 13 \\
\hline
\end{tabular}


Relationship with the local authorities. It is instructive to note that three out of the four IPs were directly affected by the various conflicts as implied by the main difficulties hampering relationships between the IPs and the local authorities (Table 12). Two IPs (Maendeleo and Muungano) were under the rebel control, while a third IP (Musanganya) was under occupation of the regular forces who had put up their headquarters there. It is only the IP Buuma that was not so affected by the conflicts.

By implication (Table 12), limited access to services provided by established government authorities was one of the biggest constraint faced by members of the three IPs particularly. The limited communication channels to reach the authorities, and the fear of the past (especially the rebel authorities) were the greatest difficulties in the relationship between the IPs and the authorities in place. In the highly militarised areas (especially in the cases of IPs Muungano and Musanganya), intimidation from both rebels and regular forces added to the problems between IP and authorities. Hence, overall difficulties that hampered relationships between IPs and government authorities are summarised in Table 12.

Conversely, IPs reverted to collaboration and other strategies (Table 13) with local traditional leaders, with whom they lived together to circumvent the constraints on relationship with the established authorities

TALE 12. Main difficulties hampering relationships between the IPs and the local authorities in Kivu Province, eastern Democratic Republic of Congo

\begin{tabular}{|c|c|c|c|c|c|}
\hline \multirow[t]{2}{*}{ Difficulties hampering relationships } & \multicolumn{4}{|c|}{ IPs } & \multirow{2}{*}{$\begin{array}{l}\text { Total number } \\
\text { of IPs } \\
\text { experiencing } \\
\text { the difficulties }\end{array}$} \\
\hline & Maendeleo & Muungano & Buuma & Musanganya & \\
\hline Limited communication channels & 1 & 0 & 1 & 1 & 3 \\
\hline Fear of rebel authority & 1 & 1 & 0 & 0 & 2 \\
\hline Military intimidation & 0 & 1 & 0 & 1 & 2 \\
\hline $\begin{array}{l}\text { Total number of difficulties hampering } \\
\text { relationships }\end{array}$ & 2 & 2 & 1 & 2 & 7 \\
\hline
\end{tabular}

TABLE 13. Strategies developed by the four IPs to improve relations with the established authorities in Kivu Province, eastern Democratic Republic of Congo

\begin{tabular}{|c|c|c|c|c|c|}
\hline \multirow[t]{2}{*}{ Strategies for improving relationships } & \multicolumn{4}{|c|}{ IPs } & \multirow{2}{*}{$\begin{array}{l}\text { Total number } \\
\text { of IPs } \\
\text { using the } \\
\text { strategies }\end{array}$} \\
\hline & Maendeleo & Muungano & Buuma & Musanganya & \\
\hline Collaboration with local leaders & 1 & 1 & 0 & 0 & 2 \\
\hline Local leaders are members of the IP & 1 & 1 & 1 & 1 & 4 \\
\hline News on local radio stations & 1 & 0 & 0 & 0 & 1 \\
\hline Sending invitations & 0 & 0 & 0 & 1 & 1 \\
\hline $\begin{array}{l}\text { Total number of strategies for improving } \\
\text { relationships }\end{array}$ & 3 & 2 & 1 & 2 & 8 \\
\hline
\end{tabular}


(Table 12). As opposed to administrative authorities (group leaders or territory administrators), the traditional authorities (the village chiefs) were not replaced during conflicts or crises. It is also interesting to note that, as a positive attribute, the local authorities have been members of the IPs since their inception, which facilitated positive exchanges between them and the IPs. In addition, the IPs Maendeleo and Musanganya had opted to other methods such as local radio announcements and sending invitations to other authorities to their activities.

\section{ACKNOWLEDGEMENT}

We are grateful to the Forum for Agricultural Research in Africa (FARA) for supporting this research. Facilitation of CIAT as the lead institution as well as holding the task force leadership of the DRC IPs is acknowledged. We appreciate the resilience of the four study IPs in DRC over the period of conflicts.

\section{REFERENCES}

Adekunle, A., Ayanwale, A., Fatunbi, O., Olarinde, I., Oduol, J., Pali, P., Tenywa, M., Mugabe, M., Mugabo, J., Wanjiku, C. and Buruchara, R. 2014. Unlocking the potential of Agricultural Research and Development in the highlands of East and Central Africa. Forum for Agricultural Research in Africa (FARA), Accra, Ghana, pp 36.

Africa Progress Panel. 2011. The Transformative Power of Partnerships, Africa Progress Report 2011. Geneva, Switzerland, pp 74.

Barhalendehwa, J. 2013. Renforcer le capital social pour une gouvernance des ressources naturelles au Bushi à l'Est de la République Démocratique du Congo en période post-conflit. In Gouvernance des ressources naturelles collectives dans les sociétés post-conflit: défis acquis et perspectives dans la région des grands lacs africains, Ed. Vertigo, Canada.

Birachi, E., van Rooyen, A., Some, H., Maute, F., Cadilhon, J., Adekunle, A. and Swaans, K. 2013. Innovation platforms for agricultural value chain development, Innovation Platforms Practice Brief 6. ILRI and the Integrated Systems for Humid Tropics CRP, Nairobi, Kenya.

Brahimi, L. 2007. Former Special Adviser of the Secretary-General of the United Nations, State building in crisis and post-conflict countries, June 2007, Available at http:// unpan1.un.org/intradoc/groups/public/ documents/un/unpan026305.pdf

CIA, 2014. Democratictic Republic of Congo. The World Factbook. Longley, V: Central Intelligence Agency. Downloaded on November 26, 2016.

FARA, 2007. Sub-Saharan Africa Challenge Programme, Medium-Term Plan 20082010. Forum for Agricultural Research in Africa, Secretariat, Accra, Ghana.

Fischer, M. 2004. Recovering from Violent Conflict: Regeneration and (Re-) Integration as Elements of Peacebuilding. Berlin: Berghof Research Center for Constructive Conflict Management, Berghof Handbook on Conflict Transformation. http://www.berghofhandbook.net/uploads/download/ fischer_handbook.pdf.

Hamre, J. J. and Sullivan, G. R. 2002. Toward post-conflict reconstruction. The Washington Quarterly 25 (4): 85-96.

Isumbisho, P.M. and Sanginga, P. 2013. Vers une Bonne Gouvernance des Ressources Naturelles dans les Sociétés Post-Conflits : Concepts, Expériences et Leçons de la Région des Grands Lacs en Afrique, Edition Vertigo.

Junne, G. et Verkoren, W. 2005. Post-conflict development: Meeting new challenges. Lynne Rienner Publishers, Boulder, London. ISBN 1-58826-327-4. 
Njingulula, P., Wimba, M., Musakamba, M., Masuki, K.F., Katafiire, M., Ugen, M. and Birachi, E. 2014. Strengthening local seed systems within the bean value chain: Experience of agricultural innovation platforms in the Democratic Republic of Congo. African Crop Science Journal 22 (s4):1003-1012.

Schut, M., Klerkx, L., Sartas, M., Lamers, D., Mc Campell, M., Ogbonna, I., Kaushik, P., Atta-Krah, K. and Leeuwis, C. 2015. Innovation Platforms: Experiences with their Institutional Embedding in Agricultural Research for Development, Experimental Agriculture, 1-25, Cambridge University Press.

Swaans, K., Cullen, B., van Rooyen, A., Adekunle, A., Ngwenya, H., Lema, Z. and Nederlof, S. 2013. Paper. Dealing with critical challenges in African innovation platforms: lessons for facilitation. Knowledge Management for Development Journal 9 (3): 116-135. Available from: http://journal.km4dev.org/

Tenywa, M.M., Farrow, A., Buruchara, R., Tukahirwa, J.M.B., Mugaba, J., Rao, K.P.C., Wanjiku, C., Nyamwaro, S.O., Kashaija, N.I., Majaliwa, M., Mapatano, S., Mugabo, J., Ngaboyisonga, C.M., Ramazine, M.A., Mutabazi, S., Fungo, B., Pali, P., Njuki, J., Abenakyo, A., Opondo, C., Nkonya, E., Njeru, R., Lubanga, L., Wimba, B., Murorunkwere, F., Kuule, M., Mandefu, P., Kamugisha, R., Fatunbi, A.O. and Adekunle, A.A. 2013a. Chapter 2: Strategies for setting up Innovation Platforms in the Lake Kivu Pilot Learning Site, pp. 20-41. In: Adekunle A Adewale, Fatunbi A Oluwole, Robin Buruchara and Sospeter Nyamwaro (Eds.). Integrated Agricultural Research for Development: from Concept to Practice, FARA, Accra, Ghana.

Tenywa, M.M., Adekunle, A.A., Fatunbi, A.O., Nyamwaro, S.O., Buruchara, R.,
Tukahirwa, J.M.B., Mugaba, J.M., Wanjiku, C., Rao, K.P.C., Kashaija, N.I., Majaliwa, M., Farrow, A., Mapatano, S., Mugabo, J.R., Ngaboyisonga, C.M., Ramazine, M.A., Mutabazi, S., Fungo, B., Pali, P., Njuki, J., Abenakyo, A., Opondo, C., Nkonya, E., Oduol, J., Njeru, R., Lubanga, L., Wimba, B., Murorunkwere, F., Kuule, M., Mandefu, P. and Kamugisha, R. 2013b. Chapter 3: Operationalisation of Innovation Platforms in the Lake Kivu Pilot Learning Site, pp. 42-60. In: Adekunle A Adewale, Fatunbi A Oluwole, Robin Buruchara and Sospeter Nyamwaro (Eds.). Integrated Agricultural Research for Development: from Concept to Practice, FARA, Accra, Ghana.

Tenywa, M.M., Rao, K.P.C., Tukahirwa, J.B., Buruchara, R., Adekunle, A.A., Mugabe, J., Wanjiku, C., Mutabazi, S., Fungo, B., Kashaija, N.I., Pali, P., Mapatano, S., Ngaboyisonga, C., Farrow, A., Njuki, J. and Abenakyo, A. 2011. Agricultural innovation platform as a tool for development oriented research: Lessons and challenges in the formation and operationalization. Journal of Agriculture \& Environmental Studies (Special Edition): Integrated Agricultural Research for Development II (1). Available at http:// learningpublics.org/component/content/ article/14-agricvolume2.

Tukahirwa, J.M.B., Tenywa, M.M., Kakuru, W., Kamugisha, R. and Nampala, M.P. 2013, Establishing Functional Innovation Platforms for Scaling Sustainable Land Management, Handbook for Facilitators. ICRAF Publications Series, pp 46.

Wikipedia. 2014. Armed Forces of the Democratic Republic of the Congo. The Free Encyclopedia.

World Bank, 2011. World Development Report 2011: Conflict, Security, and Development, Word Bank, Washington, DC, USA. 